
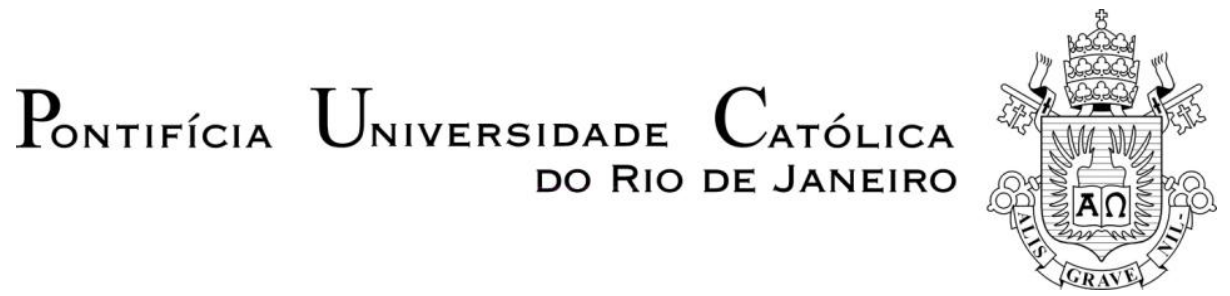

João Dalla Rosa Júnior

\title{
Design e memória: \\ a economia simbólica da produção de Ronaldo Fraga
}

Dissertação de Mestrado

Dissertação apresentada como requisito parcial para obtenção do grau de Mestre pelo Programa de PósGraduação em Design do Departamento de Artes \& Design da PUC-Rio.

Orientador: Prof. Alberto Cipiniuk 


\title{
Pontifícia Universidade Católica \\ DO RIO DE JANEIRO
}

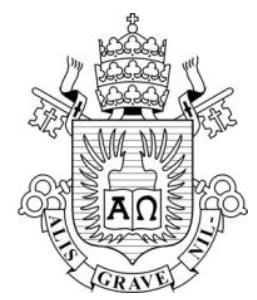

João Dalla Rosa Júnior

\begin{abstract}
Design e memória: a economia simbólica da produção de Ronaldo Fraga
\end{abstract}

Dissertação apresentada ao Programa de PósGraduação em Design da PUC-Rio como requisito parcial para obtenção do grau de Mestre em Design. Aprovada pela Comissão Examinadora abaixo assinada.

Prof. Alberto Cipiniuk

Orientador

Departamento de Arte \& Design - PUC-Rio

Profa. Leila Lemgruber Queiroz Departamento de Arte \& Design - PUC-Rio

Profa. Kathia Castilho Cunha Universidade Anhembi Morumbi

Profa. Denise Berruezo Portinari Coordenadora Setorial do Centro de Teologia e Ciências Humanas - PUC-Rio

Rio de Janeiro, 26 de março de 2012 
Todos os direitos reservados. É proibida a reprodução total ou parcial do trabalho sem autorização da universidade, do autor e do orientador.

João Dalla Rosa Júnior

Graduou-se em Artes Plásticas pela Universidade Federal do Rio Grande do Sul em 2005. Especializou-se em Design de Moda pela Faculdade SENAI / CETIQT em 2010 e em Cultura e Arte Barroca pela Universidade Federal de Ouro Preto em 2008. Com experiência em Artes Plásticas e Moda, atua como docente nos cursos de graduação em Design de Moda e Design de Superfície da Faculdade SENAI/CETIQT e nos cursos de Especialização em Design de Moda e Design de Estampas da mesma instituição.

Ficha Catalográfica

Rosa Junior, João Dalla

Design e memória: a economia simbólica da produção de Ronaldo Fraga / João Dalla Rosa Junior ; orientador: Alberto Cipiniuk. - 2012.

$200 \mathrm{f.}$ : il. (color.) ; $30 \mathrm{~cm}$

Dissertação (mestrado)-Pontifícia Universidade Católica do Rio de Janeiro, Departamento de Artes e Design, 2012.

Inclui bibliografia

1. Artes e design - Teses. 2. Design. 3. Moda. 4. Vestuário. 5. Memória. 6. Economia simbólica. 7. Fraga, Ronaldo. I. Cipiniuk, Alberto. II. Pontifícia Universidade Católica do Rio de Janeiro. Departamento de Artes \& Design. III. Título.

CDD: 700 


\section{Agradecimentos}

Ao meu orientador, Professor Alberto Cipiniuk, pela confiança, estímulo e parceria no desenvolvimento deste trabalho.

À CAPES e à PUC-Rio, pelos auxílios concedidos sem os quais este trabalho não seria realizado.

À minha família pelo apoio incondicional em todas as minhas aventuras.

Aos amigos pelo carinho, atenção e incentivo nas presenças e ausências.

A Luciane Fortes, Christina Rangel, Gaspar Carlini, Heloisa Helena, Rodrigo Monteiro e João Cícero, pelos diálogos que me ajudaram na composição deste trabalho.

Aos colegas do GRUDAR pela experiência coletiva na busca e na construção do conhecimento.

Aos colegas de MoDuS por compartilharem as questões do campo de estudo e, em especial, a Deborah, por mediar e incentivar os primeiros laços que resultaram nesta pesquisa.

Aos colegas do SENAI/CETIQT e, em especial, ao coordenador e amigo Sérgio, pelo apoio na conciliação de pesquisa e trabalho. 
Aos professores que participaram da Comissão Examinadora e a todos aqueles com os quais pude compartilhar alguns momentos desta pesquisa.

Aos colegas de mestrado e, principalmente, ao Karl, pelas certezas e incertezas deste convívio de dois anos.

A todos aqueles que me ajudaram a trilhar os caminhos desta trajetória. 


\section{Resumo}

Junior, João Dalla Rosa; Cipiniuk, Alberto (Orientador). Design e memória: a economia simbólica da produção de Ronaldo Fraga. Rio de Janeiro, 2012. 200p. Dissertação de Mestrado Departamento de Artes e Design, Pontifícia Universidade Católica do Rio de Janeiro.

A presente pesquisa tem por objetivo estabelecer a relação entre a prática do design e a memória social, tendo em vista a compreensão do contexto da produção de bens simbólicos sob o fenômeno da moda e da temporalidade da sociedade capitalista e industrial. Através do conteúdo narrativo sobre as referências do passado presentes na produção de Ronaldo Fraga, propomos uma análise teórica acerca da prática social do design, colocando em questão as associações entre as representações da memória social e a produção de objetos de vestuário. A partir de uma abordagem sociológica, identificamos os aspectos coletivos da prática do design, destacando as características da produção de Fraga e enfatizando como a lógica da moda articula os valores da memória em uma economia simbólica. Neste sentido, investigamos as formas pelas quais as memórias são transformadas em produtos no mundo do vestuário. Exploramos a noção de coleção de moda, de tradição e de narrativa no desenvolvimento do design-história. Dedicamo-nos, também, a examinar como a moda, enquanto campo de produção cultural, se estrutura a partir de relações temporais específicas, cuja função da memória fornece particularidades aos valores econômicos em jogo na prática de produção do vestuário. Assim, nos concentramos no papel desempenhado por Ronaldo Fraga no contexto de inclusão da moda ao Ministério da Cultura e na exposição Rio São Francisco como o lugar consagrado que representa a relação entre a prática em design e a memória social.

\section{Palavras-chave}

Design; Moda; Vestuário; Memória; Economia Simbólica; Ronaldo Fraga; 


\section{Abstract}

Junior, João Dalla Rosa; Cipinuk, Alberto (Advisor). Design and memory: the symbolic economy of production of Ronaldo Fraga. Rio de Janeiro, 2012. 200p. MSc. Dissertation Departamento de Artes e Design, Pontifícia Universidade Católica do Rio de Janeiro.

This research aims to establish the relationship between design practice and social memory in order to understand the context of the production of symbolic goods in the phenomenon of fashion and the temporality of capitalist and industrial society. Through the narrative content of the references of the past present in the production of Ronaldo Fraga, we propose a theoretical analysis about the social practice of design, putting in question the associations between social memory representations of objects and the production of clothing. From a sociological approach, we identified the collective aspects of the design practice, highlighting the characteristics of the production of Fraga and emphasizing how the logic of fashion articulates the values of memory in a token economy. In this sense, we investigate the ways in which memories are transformed into products in the world of clothing. We explore the notion of fashion collection, tradition and narrative in the development of design-history. We also examine how fashion, as the field of cultural production, is structured from a specific temporal relation, which memory function to provide particular economic values at stake in the practice of garment production. Thus, we focus on the role played by Ronaldo Fraga to the context of the inclusion of fashion to the Ministry of Culture and the display of Rio San Francisco as the place devoted to the relationship between design practice and social memory.

\section{Keywords}

Design; Fashion; garment; Memory; simbolic economy; Ronaldo Fraga; 


\section{Sumário}

1. Introdução

2. Design e o tempo dos lugares 18

2.1. As referências do passado 19

2.2. O novo 23

2.3. A compressão de tempo e de espaço 29

2.4. Ronaldo Fraga: roupas e memórias 33

2.5. Design e os lugares de memória 39

3. A aventura da memória-moda 44

3.1. A moda da memória 48

3.2. A memória em moda $\quad 51$

3.3. Entre memória e história 59

3.4. O objeto e a prática do design-história 63

4. As formas do design-história 70

4.1. Coleção 70

4.2. Tradição $\quad 81$

4.3. Narrativa 93

5. Por uma política cultural da memória-moda 107

5.1. Moda: capital versus tempo 111

5.1.1. Periodização 114

5.1.2. Sucessão 117

5.2. Narrativas e silêncios 121

5.3. Afinal, quem navega? 135

6. Conclusão 140 
8. Anexos 150

8.1. Palestra de Ronaldo Fraga - Casa Fiat 150

8.2. Entrevista com Ronaldo Fraga - Plaza na Moda 152

8.3. Entrevista com Ronaldo Fraga - Entrelinhas 154

8.4. Entrevista com Ronaldo Fraga - TV Catarina 156

8.5. Reportagem com Ronaldo Fraga - Programa Ação 159

8.6. Entrevista com Ronaldo Fraga - Comunidade Moda 162

8.7. Vídeo O Chico morre no mar - Exposição Rio São 164 Francisco

8.8. Entrevista Ronaldo Fraga - Programa Roda Viva 165

8.9. Entrevistas - Exposição Rio São Francisco 188

8.10. Folder da exposição Rio São Francisco 198

8.11. Carta de Ronaldo Fraga - Coleção de Inverno 2012 
O eterno, de qualquer modo, é, antes, um drapeado de vestido do que uma ideia.

[...] A própria moda é apenas um outro meio que $o$ atrai ainda mais profundamente ao mundo da matéria.

Walter Benjamin, Passagens [Moda]. 